\title{
12
}

\section{Location determinants and provincial distribution of FDI}

\section{Chen Chunlai}

Foreign direct investment into China has been one of the most important aspects of the overall economic reform program launched in China 25 years ago. The gradual but active liberalisation of the FDI regime and improvements in the investment environment greatly increased the confidence of foreign investors to do business in China. Consequently, FDI inflows into China increased rapidly after 1979 and particularly during the 1990s. In 2002, with its accession to the World Trade Organization (WTO), China surpassed the United States in becoming the largest FDI recipient in the world.

The eastern provinces account for nearly 90 per cent of the total. What are the causes of the uneven provincial distribution of FDI inflows into China, the provincial characteristics that determine FDI location decisions within China, and the relative attractiveness to FDI of mainland China's 31 provinces given their specific provincial characteristics?

\section{FDI INFLOWS INTO CHINA, 1979-2002}

Though China first started to attract FDI in late 1979, massive FDI inflows began after 1992. Table 12.1 and Figure 12.1 present data on FDI inflows into China from 1979 to 2002, a period characterised by two distinct phases: 1979-91 and 19922002.

In the initial period of the first phase, following the establishment of the four Special Economic Zones (SEZs) ${ }^{1}$ with their special incentives for FDI, inflows into China 
Table 12.1 Actual FDI inflows into China, 1979-2002

(US\$ million, current prices)

\begin{tabular}{lccc}
\hline Year & FDI inflow & Year & FDI inflow \\
1979 & 109 & 1992 & 11,007 \\
1980 & 195 & 1993 & 27,515 \\
1981 & 375 & 1994 & 33,767 \\
1982 & 440 & 1995 & 37,521 \\
1983 & 636 & 1996 & 41,725 \\
1984 & 1,258 & 1997 & 45,257 \\
1985 & 1,661 & 1998 & 45,463 \\
1986 & 1,874 & 1999 & 40,398 \\
1987 & 2,314 & 2000 & 40,715 \\
1988 & 3,194 & 2001 & 46,878 \\
1989 & 3,392 & 2002 & 52,743 \\
1990 & 3,487 & $1979-2002$ & 405,982 \\
1991 & 4,366 & &
\end{tabular}

Source: State Statistical Bureau, various issues, 1986-2002. Zhongguo Tongji Nianjian [China Statistical Yearbook], Zhongguo Tongji Chubanshe, Beijing.

Figure 12.1 Actual FDI inflows into China, 1979-2002 (current prices)

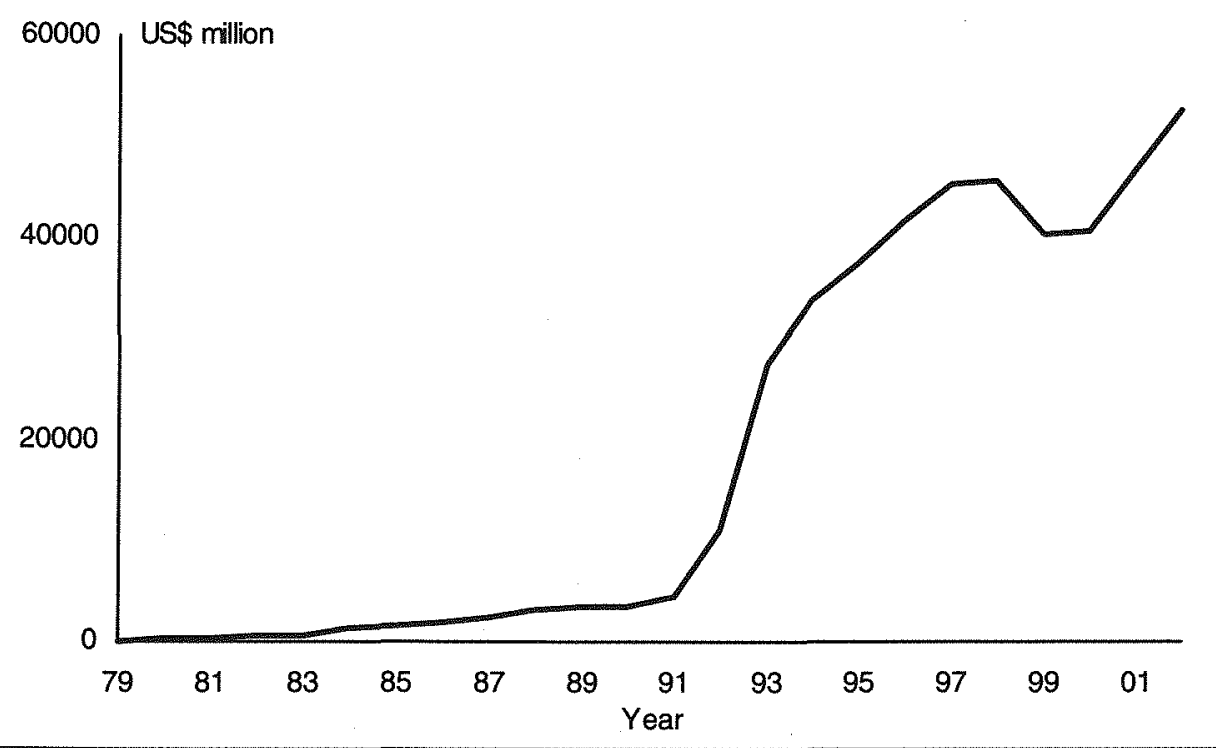

Source: As Table 12.1. 
were highly concentrated in Guangdong and Fujian provinces, and particularly in the four SEZs. The Chinese government was very cautious about introducing FDI into its domestic economy and foreign investors were also cautious about making investments in China in the initial stages of China's opening up to the outside world, so that initial FDI inflows were relatively small.

In 1984, Hainan Island and 14 coastal cities across ten provinces ${ }^{2}$ opened to FDI. Special economic policies were introduced in these open coastal cities. In 1984, inflows of FDI into China were double those of 1983. Major efforts were made over the next 7 years to attract FDI inflows. More and more areas and regions were opened to FDI, including the Yangzi River delta, the Pearl River delta, the Min Nan region, the Shanghai Pudong New Development Area and the entire coastal region. A series of new laws and regulations was introduced to encourage FDI, with considerable success.

In the Spring of 1992, Deng Xiaoping made a tour to the economically open areas and SEZs on China's southern coast. His aims were to push China's overall economic reform process forward, and to increase foreign investors' confidence in China's open-door policy and market-oriented economic reform. Deng praised the FDl-driven economic development in the economically open areas and SEZs, and called for acceleration of liberalisation. Deng's visit, which turned out to be a landmark, set the scene for China's move away from the uneven regional priority system towards nationwide implementation of open policies for FDI. The Chinese government then adopted and implemented a series of new policies and regulations to encourage FDI inflows. The response was astounding. From 1992, inflows of FDI into China increased dramatically, reaching US\$45 billion in 1998.

In 1999, mainly because of the impact of the East Asian financial crisis, FDI inflows into China dropped for the first time since 1979. When China acceded to the WTO in 2001 the situation changed dramatically: FDI inflows into China rose to US $\$ 47$ billion, an increase of 13 per cent over 2000. In 2002, FDI inflows increased by another 11 per cent from 2001 , reaching US $\$ 53$ billion. In 2002, China surpassed the United States to become the largest FDI recipient in the world.

\section{PROVINCIAL DISTRIBUTION OF FDI INFLOWS}

To facilitate the analysis of the regional and provincial distribution of FDI inflows into China, we group China's 31 mainland provinces into three regions-East, Central and West. ${ }^{3}$ 
Tables 12.2-12.3 and Figures 12.2-12.3 provide basic statistics on the distribution of FDI among China's 31 mainland provinces and three regions from 1983-2002. Several important features can be made out here. First, as Table 12.2 shows, FDI inflows into China in the 1980s were overwhelmingly concentrated in the four special economic zones (SEZs) and the two municipalities of Beijing and Shanghai. The combined shares of Guangdong, Fujian, Beijing and Shanghai accounted for about 70 per cent of the national total from 1983 to 1991.

With the development of overall economic reform and the nationwide implementation of open policies for FDI in the 1990s, FDI inflows into China gradually spread to other provinces. Increasingly, the most important areas for hosting FDI have been the Yangzi River Delta, including Shanghai, Jiangsu, and Zhejiang, and the Bohai Gulf, including Shandong, Hebei, Tianjin, and Liaoning. Several central provinces (Jilin, Heilongjiang, Jiangxi, Henan, Hubei and Hunan) and two western provinces (Sichuan and Shaanxi) also witnessed relatively large increases in FDI inflows from 1992 to 2002. Thus, since the early 1990s, FDI inflows have diffused from the initially concentrated southern coastal areas towards the southeastern and eastern coastal areas as well as inland.

Second, for the East region provinces, FDI inflows have increased steadily and remarkably quickly, particularly during the periods 1992-1998 and 2001-2002 (Figure 12.2).

Third, the East region has overwhelmingly dominated the other two province groups in stocks of FDI (Table 12.3 and Figure 12.3). The percentage shares of accumulated FDI stocks were 88 per cent for the East, 9 per cent for the Central region, and only 3 per cent for the West.

Guangdong's accumulated FDI stock from 1983 to 2002 was 28 per cent of the national total, far exceeding the secopnd, third and fourth provinces (Jiangsu, Fujian and Shanghai). However, Guangdong's dominance in attracting FDI inflows has declined gradually over the past two decades. Its share of China's FDI stock fell from 46 per cent in the 1980s to 27 per cent in the 1990s. In contrast, the shares of other coastal provinces, notably Jiangsu, Fujian, Zhejiang, Shandong, Tianjin and Hebei, have increased steadily.

The share of the Central provinces in national accumulated FDI stocks has increased gradually, from 5 per cent during the 1980 s to 9 per cent during the 1990s. The main contributors are Henan, Hubei, and Hunan; from the 1980 s to the 1990 s 
Table 12.2 Actual FDI inflows into China's provinces, 1983-2002 (millions of US dollars at 1995 prices)

\begin{tabular}{|c|c|c|c|c|c|c|c|c|c|}
\hline Province & 1983 & 1984 & 1985 & 1986 & 1987 & 1988 & 1989 & 1990 & 1991 \\
\hline Beijing & 116 & 52 & 126 & 208 & 142 & 648 & 393 & 325 & 274 \\
\hline Tianjin & 7 & 15 & 79 & 71 & 179 & 79 & 39 & 43 & 148 \\
\hline Hebei & 2 & 7 & 12 & 16 & 14 & 25 & 54 & 52 & 64 \\
\hline Shanxi & - & - & 1 & - & 7 & 8 & 12 & 4 & 4 \\
\hline Inner Mongolia & 5 & - & 4 & 10 & 7 & 8 & 5 & 12 & 2 \\
\hline Liaoning & 11 & 11 & 36 & 67 & 122 & 168 & 155 & 300 & 405 \\
\hline Jilin & - & - & 7 & 34 & 10 & 12 & 12 & 21 & 35 \\
\hline Heilongjiang & 1 & 2 & 6 & 34 & 19 & 89 & 71 & 33 & 23 \\
\hline Shanghai & 16 & 62 & 154 & 207 & 287 & 300 & 519 & 203 & 162 \\
\hline Jiangsu & 14 & 30 & 47 & 47 & 116 & 162 & 156 & 156 & 245 \\
\hline Zhejiang & 4 & 12 & 38 & 34 & 49 & 56 & 66 & 57 & 103 \\
\hline Anhui & - & - & 4 & 49 & 4 & 36 & 11 & 16 & 12 \\
\hline Fujian & 25 & 74 & 168 & 87 & 74 & 187 & 428 & 373 & 527 \\
\hline Jiangxi & 0 & 10 & 15 & 13 & 7 & 12 & 11 & 9 & 22 \\
\hline Shandong & 4 & 7 & 51 & 91 & 87 & 116 & 200 & 217 & 242 \\
\hline Henan & - & - & 12 & 15 & 18 & 83 & 57 & 13 & 43 \\
\hline Hubei & - & - & 11 & 17 & 35 & 29 & 35 & 37 & 52 \\
\hline Hunan & 3 & 4 & 39 & 14 & 4 & 17 & 29 & 17 & 29 \\
\hline Guangdong & 612 & 953 & 922 & 1199 & 988 & 1,611 & 1,626 & 1845 & 2,174 \\
\hline Guangxi & 10 & 33 & 44 & 68 & 60 & 27 & 65 & 42 & 36 \\
\hline Hainan & - & - & - & - & - & 151 & 117 & 120 & 198 \\
\hline Chongqing &.. & .. & .. & .. & .. & .. & .. & .. & 72 \\
\hline Sichuan & 29 & 12 & 41 & 44. & 33 & 52 & 16 & 28 & 18 \\
\hline Guizhou & - & 1 & 14 & 17 & - & 13 & 15 & 12 & 16 \\
\hline Yunnan & - & - & 2 & 5 & 9 & 11 & 10 & 8 & 4 \\
\hline Tibet & - & - & - & - & - & - & - & - & - \\
\hline Shaanxi & 4 & 10 & 22 & 52 & 98 & 144 & 119 & 55 & 36 \\
\hline Gansu & 20 & - & 1 & 2 & - & 3 & - & 2 & 5 \\
\hline Qinghai & - & 1 & - & - & - & 4 & - & - & - \\
\hline Ningxia & - & - & - & - & - & - & 1 & - & - \\
\hline Xinjiang & " & 3 & 16 & 20 & 24 & 7 & 1 & 6 & - \\
\hline East region & 820 & 1256 & 1,677 & 2,095 & 2,118 & 3,530 & 3,818 & 3,733 & 4,578 \\
\hline Central region & 10 & 15 & 98 & 185 & 110 & 294 & 243 & 161 & 222 \\
\hline West region & 53 & 27 & 96 & 139 & 163 & 233 & 163 & 113 & 152 \\
\hline National total & 882 & 1299 & 1870 & 2420 & 2391 & 4056 & 4224 & 4007 & 4,951 \\
\hline
\end{tabular}


Table 12.2 Actual FDI inflows into China's provinces, 1983-2002 (continued)

\begin{tabular}{|c|c|c|c|c|c|c|}
\hline Province & 1992 & 1993 & 1994 & 1995 & 1996 & 1997 \\
\hline Beijing & 380 & 703 & 1410 & 1,080 & 1,508 & 1,512 \\
\hline Tianjin & 117 & 552 & 1044 & 1,521 & 1,948 & 2,385 \\
\hline Hebei & 123 & 418 & 538 & 547 & 802 & 1,045 \\
\hline Shanxi & 59 & 91 & 33 & 64 & 134 & 253 \\
\hline Inner Mongolia & 6 & 90 & 41 & 58 & 70 & 70 \\
\hline Liaoning & 561 & 1349 & 1481 & 1,425 & 1,687 & 2,093 \\
\hline Jilin & 82 & 290 & 249 & 408 & 438 & 382 \\
\hline Heilongjiang & 78 & 245 & 357 & 517 & 532 & 698 \\
\hline Shanghai & 536 & 3332 & 2543 & 2,893 & 3,826 & 4,012 \\
\hline Jiangsu & 1589 & 2998 & 3869 & 5,191 & 5,058 & 5,161 \\
\hline Zhejiang & 260 & 1088 & 1183 & 1,258 & 1,476 & 1,428 \\
\hline Anhui & 60 & 272 & 380 & 483 & 492 & 413 \\
\hline Fujilan & 1546 & 3031 & 3818 & 4,044 & 3,966 & 3,985 \\
\hline Jiangxi & 108 & 220 & 269 & 289 & 292 & 454 \\
\hline Shandong & 1090 & 1976 & 2625 & 2,689 & 2,515 & 2,367 \\
\hline Henan & 58 & 322 & 398 & 479 & 508 & 657 \\
\hline Hubei & 221 & 570 & 619 & 625 & 660 & 750 \\
\hline Hunan & 144 & 461 & 341 & 508 & 683 & 871 \\
\hline Guangdong & 4019 & 7966 & 9730 & 10,260 & 11,285 & 11,119 \\
\hline Guangxi & 198 & 933 & 860 & 673 & 637 & 835 \\
\hline Hainan & 491 & 746 & 944 & 1,062 & 766 & 670 \\
\hline Chongqing & 31 & 209 & 418 & 259 & 212 & 365 \\
\hline Sichuan & 91 & 394 & 530 & 283 & 219 & 236 \\
\hline Guizhou & 22 & 45 & 65 & 57 & 31 & 47 \\
\hline Yunnan & 31 & 102 & 67 & 98 & 64 & 157 \\
\hline Tibet & - & - & - & - & - & - \\
\hline Shaanxi & 49 & 247 & 246 & 324 & 316 & 596 \\
\hline Gansu & - & 13 & 90 & 64 & 87 & 39 \\
\hline Qinghai & 1 & 3 & 3 & 2 & 1 & 2 \\
\hline Ningxia & 4 & 13 & 8 & 4 & 5 & 6 \\
\hline Xinijiang & - & 56 & 50 & 55 & 62 & 24 \\
\hline East Region & 10,909 & 25,090 & 30,043 & 32,641 & 35,474 & 36,612 \\
\hline Central Region & 814 & 2,560 & 2,686 & 3,429 & 3,810 & 4,546 \\
\hline West Region & 229 & 1,082 & 1,475 & 1,145 & 996 & 1,474 \\
\hline National Total & 11,953 & 28,731 & 34,205 & 37,216 & 40,280 & 42,631 \\
\hline
\end{tabular}


Table 12.2 Actual FDI inflows into China's provinces, 1983-2002 (continued)

\begin{tabular}{|c|c|c|c|c|c|}
\hline Province & 1998 & 1999 & 2000 & 2001 & 2002 \\
\hline Beijing & 2,026 & 1,881 & 1,490 & 1,544 & 1,474 \\
\hline Tianjin & 1,975 & 1,680 & 1,032 & 1,863 & 1,352 \\
\hline Hebei & 1,335 & 992 & 601 & 585 & 669 \\
\hline Shanxi & 229 & 373 & 199 & 204 & 181 \\
\hline Inner Mongolia & 85 & 62 & 94 & 94 & 151 \\
\hline Liaoning & 2,047 & 1,011 & 1,809 & 2,198 & 2,916 \\
\hline Jilin & 382 & 287 & 298 & 295 & 209 \\
\hline Heilongjiang & 492 & 303 & 266 & 298 & 304 \\
\hline Shanghai & 3,3656 & 2,702 & 2,797 & 3,748 & 3,652 \\
\hline Jiangsu & 6,198 & 5,788 & 5,686 & 6,039 & 8,709 \\
\hline Zhejiang & 1,232 & 1,174 & 1,427 & 1,932 & 2,629 \\
\hline Anhui & 259 & 249 & 282 & 294 & 328 \\
\hline Fujian & 3,937 & 3,832 & 3,037 & 3,422 & 3,281 \\
\hline Jiangxi & 435 & 306 & 201 & 346 & 925 \\
\hline Shandong & 2,059 & 2,151 & 2,629 & 3,075 & 4,046 \\
\hline Henan & 576 & 497 & 499 & 400 & 346 \\
\hline Hubel & 909 & 871 & 835 & 1,038 & 1,220 \\
\hline Hunan & 765 & 623 & 600 & 708 & 769 \\
\hline Guangdong & 11,234 & 11,102 & 9,983 & 10,421 & 9,687 \\
\hline Guangxi & 828 & 605 & 464 & 336 & 357 \\
\hline Hainan & 670 & 461 & 381 & 408 & 438 \\
\hline Chongqing & 403 & 228 & 216 & 224 & 167 \\
\hline Sichuan & 471 & 325 & 387 & 508 & 475 \\
\hline Guizhou & 42 & 39 & 22 & 25 & 33 \\
\hline Yunnan & 136 & 147 & 113 & 56 & 96 \\
\hline Tibet & - & - & - & - & - \\
\hline Shaanxi & 281 & 231 & 255 & 307 & 308 \\
\hline Gansu & 36 & 39 & 55 & 65 & 52 \\
\hline Qinghai & - & 4 & - & 32 & 40 \\
\hline Ningxia & 17 & 49 & 15 & 15 & 19 \\
\hline Xinjiang & 20 & 23 & 17 & 18 & 16 \\
\hline East Region & 36,907 & 33,381 & 31,337 & 35,570 & 39,209 \\
\hline Central Region & 4,131 & 3,569 & 3,274 & 3,675 & 4,432 \\
\hline West Region & 1,407 & 1,084 & 1,081 & 1,250 & 1,206 \\
\hline National Total & 42,444 & 38,033 & 35,693 & 40,495 & 44,847 \\
\hline
\end{tabular}

Sources: Data for 1983-91 are calculated from the State Statistical Bureau, 1992. Zhongguo Duiwai Jingji Tongji Daquan 1979-1991 [China Foreign Economic Statistics 1979-1991], China Statistical Information \& Consultancy Service Centre, Beijing. Data for 1992-2002 are calculated from the State Statistical Bureau, 1986-2002. Zhongguo Tongji Nianjian [China Statistical Yearbook], Zhongguo Tongji Chubanshe, Beijing. 
Table 12.3 Accumulated FDI stock in China's provinces, 1983-2002

(1995 constant US\$ prices)

\begin{tabular}{|c|c|c|c|c|c|c|}
\hline \multirow[b]{2}{*}{ Province } & \multicolumn{2}{|c|}{ 1983-1991 } & \multicolumn{2}{|c|}{ 1992-2002 } & \multicolumn{2}{|c|}{$1983-2002$} \\
\hline & $\begin{array}{l}\text { FDI stock } \\
\text { (US\$ mn) }\end{array}$ & $\begin{array}{c}\text { Share } \\
(\%)\end{array}$ & $\begin{array}{l}\text { FDI stock } \\
\text { (US\$ mn) }\end{array}$ & $\begin{array}{c}\text { Share } \\
(\%)\end{array}$ & $\begin{array}{l}\text { FDI stock } \\
\text { (US\$ mn) }\end{array}$ & $\begin{array}{c}\text { Share } \\
(\%)\end{array}$ \\
\hline Beijing & 2,284 & 8.75 & 15,009 & 3.79 & 17,293 & 4.09 \\
\hline Tianjin & 660 & 2.53 & 15,469 & 3.90 & 16,128 & 3.82 \\
\hline Hebei & 244 & 0.93 & 7,655 & 1.93 & 7,899 & 1.87 \\
\hline Shanxi & 36 & 0.14 & 1,818 & 0.46 & 1,854 & 0.44 \\
\hline Inner Mongolia & 54 & 0.21 & 819 & 0.21 & 872.39 & 0.21 \\
\hline Liaoning & 1,276 & 4.89 & 18,576 & 4.68 & 19,852 & 4.70 \\
\hline Jilin & 131 & 0.50 & 3,321 & 0.84 & 3,452 & 0.82 \\
\hline Heilongjiang & 278 & 1.06 & 4,091 & 1.03 & 4,368 & 1.03 \\
\hline Shanghai & 1,911 & 7.32 & 33,405 & 8.42 & 35,316 & 8.36 \\
\hline Jiangsu & 973 & 3.73 & 56,287 & 14.19 & 57,259 & 13.55 \\
\hline Zhejiang & 419 & 1.61 & 15,086 & 3.80 & 15,506 & 3.67 \\
\hline Anhui & 132 & 0.51 & 3,510 & 0.89 & 3,642 & 0.86 \\
\hline Fujian & 1,943 & 7.45 & 37,897 & 9.56 & 39,840 & 9.43 \\
\hline Jiangxi & 98 & 0.38 & 3,843 & 0.97 & 3,941 & 0.93 \\
\hline Shandong & 1,014 & 3.89 & 27,221 & 6.86 & 28,236 & 6.68 \\
\hline Henan & 240 & 0.92 & 4,738 & 1.19 & 4,978 & 1.18 \\
\hline Hubei & 217 & 0.83 & 8,318 & 2.10 & 8,535 & 2.02 \\
\hline Hunan & 153 & 0.59 & 6,472 & 1.63 & 6,625 & 1.57 \\
\hline Guangdong & 11,930 & 45.71 & 106,807 & 26.93 & 118,737 & 28.09 \\
\hline Guangxi & 385 & 1.47 & 6,725 & 1.70 & 7,109 & 1.68 \\
\hline Hainan & 586 & 2.24 & 7,037 & 1.77 & 7,623 & 1.80 \\
\hline Chongqing & 72 & 0.28 & 2,731 & 0.69 & 2,804 & 0.66 \\
\hline Sichuan & 273 & 1.04 & 3,918 & 0.99 & 4,191 & 0.99 \\
\hline Guizhou & 88 & 0.34 & 428 & 0.11 & 516 & 0.12 \\
\hline Yunnan & 49 & 0.19 & 1,067 & 0.27 & 1,116 & 0.26 \\
\hline Tibet & 0 & 0 & 0 & 0 & 0 & 0 \\
\hline Shaanxi & 539 & 2.06 & 3,159 & 0.80 & 3,698 & 0.88 \\
\hline Gansu & 32 & 0.12 & 542 & 0.14 & 574 & 0.14 \\
\hline Qinghai & 5 & 0.02 & 88 & 0.02 & 93 & 0.02 \\
\hline Ningxia & 3 & 0.01 & 155 & 0.04 & 158 & 0.04 \\
\hline Xinjiang & 76 & 0.29 & 340 & 0.09 & 416 & 0.10 \\
\hline East Region & 23,624 & 90.52 & 347,174 & 87.55 & 370,797 & 87.74 \\
\hline Central Region & 1,338 & 5.13 & 36,927 & 9.31 & 38,266 & 9.05 \\
\hline West Region & 1,137 & 4.35 & 12,428 & 3.14 & 13,565 & 3.21 \\
\hline Total & 26,099 & 100 & 396,528 & 100 & 422,627 & 100 \\
\hline
\end{tabular}

Sources: As for Table 12.2. 
Figure 12.2 FDI inflows into China, by region, 1984-2002 ( 1995 constant US $\$$ prices)

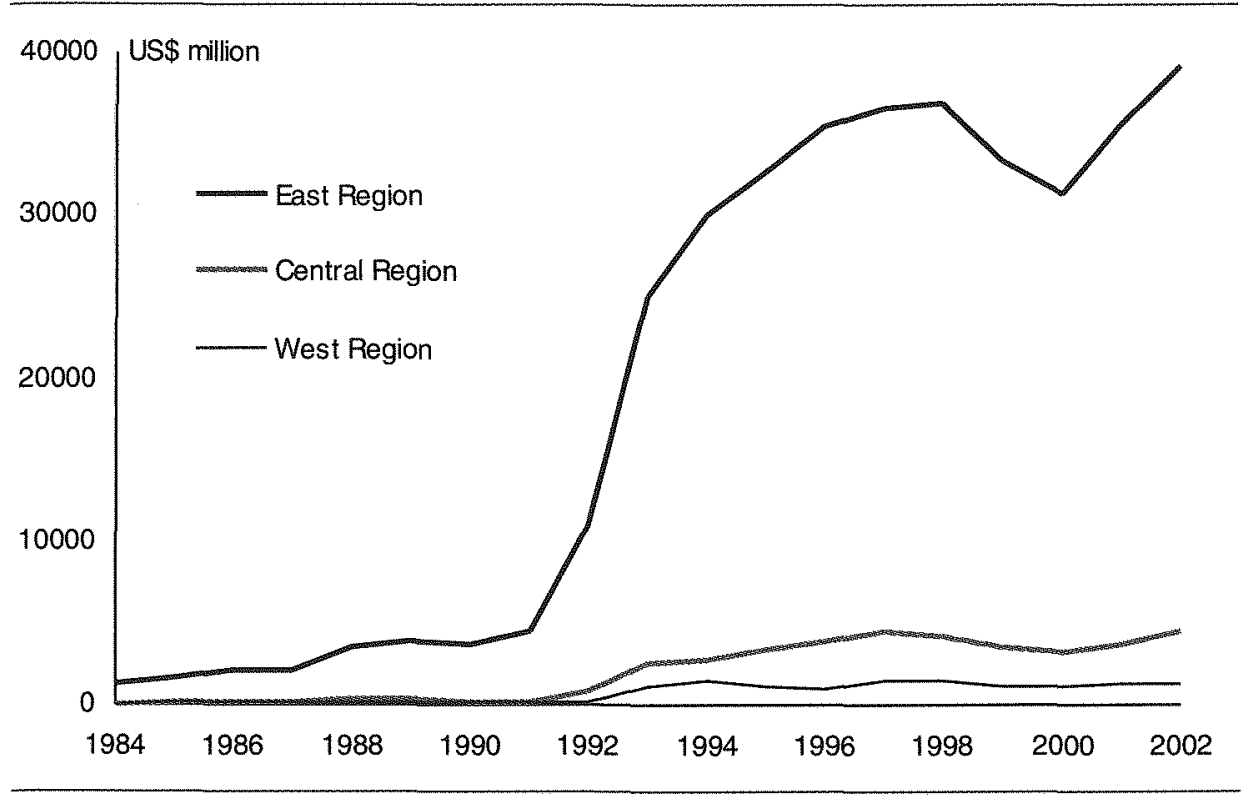

Figure 12.3 FDI stocks in China, by region, 1983-2002 (1995 constant US\$ prices)

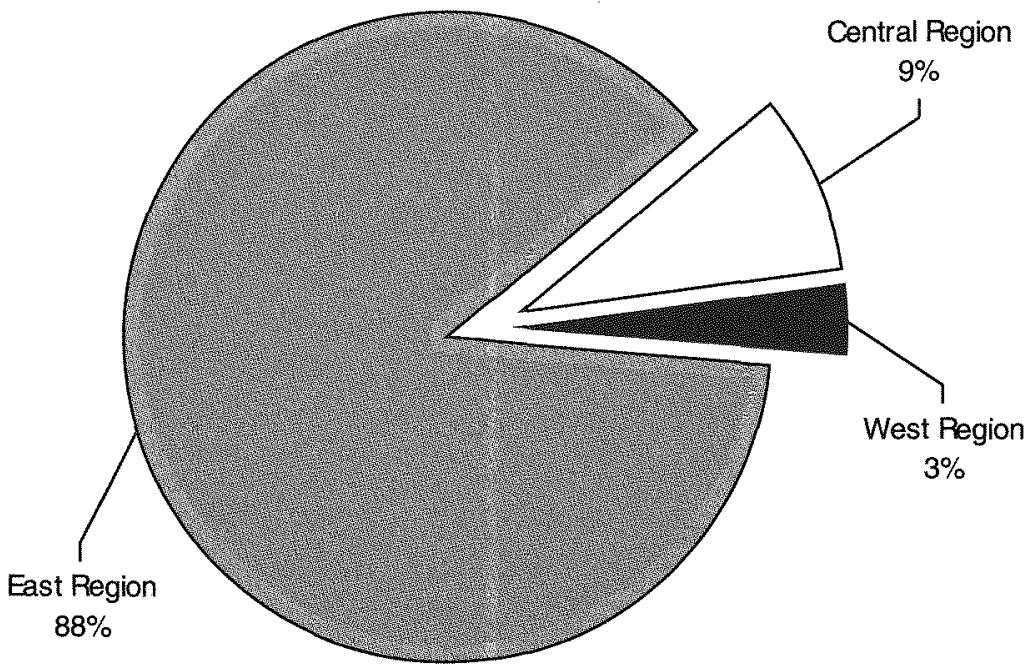


their shares of accumulated FDI in the national total doubled. This situation suggests that the provincial distribution of FDI inflows has spread from the opened coastal provinces to the inland provinces.

The less developed western provinces received little FDI. Their share in national accumulated FDI stocks declined from 4 per cent in the 1980 s to 3 per cent in the 1990s. Sichuan and Shaanxi, however, attracted more FDI inflows than other western provinces.

\section{LOCATION DETERMINANTS OF FDI DISTRIBUTION WITHIN CHINA: THE HYPOTHESES}

The theoretical framework adopted in this study is Dunning's 'OLl' explanation of FDI (Dunning 1993). According to the 'OLI' framework, for a firm to conduct FDI it must possess certain kinds of firm-specific ownership advantage. A firm's ownership advantage could be a product or a production process to which other firms do not have access, such as a patent or blueprint. It gives the firm valuable market power or cost advantage that outweighs the disadvantages of doing business abroad. In addition, the foreign market must offer a location advantage that makes it profitable for a firm to produce the product there rather than meeting demand from production at home. Location advantages include resource endowments and such economic and social factors as market size and structure, prospects for market growth and the cultural, legal, political and institutional environment, and government legislation and policies. Finally, the multinational enterprise must have an internalisation advantage. If a company owns a proprietary product or production process and it is advantageous for it to supply a foreign market through production in that market, it is still not obvious that the company should set up a foreign subsidiary. One alternative is to license a foreign firm to produce the product or use the production process. However, the product or process is exploited internally rather than at arm's length through markets because of failures in the transaction of such intangible assets. This is what is referred to as an internalisation advantage.

On the basis of Dunning's 'OLI' paradigm, the determinants of FDI can be classified into two groups-source-side and host-side factors. The source-side factors are ownership advantages and internalisation advantages and the host-side factors are location advantages. Empirically, scholars have tested the two sets of determinants either together or separately (Dunning 1993:148-79). Some empirical studies of host-side factors have shown that location determinants are very important in 
affecting the distribution of FDI inflows into host countries (Scaperlanda and Mauer 1969; Riedel 1975; Lim 1983; Nigh 1985; Torrisi 1985; Hultman and McGee 1988; Coughlin et al. 1991; Wheeler and Mody 1992; Balasubramanyam and Greenaway 1994; Milner and Pentecost 1994; Zhang Leyin 1994; Wei Shangin 1995; Chen ChienHsun 1996; Chen Chunlai 1997a, 1997b; Broadman and Sun 1997). Using the same methodology, this study will focus upon host-side factors to explore the location determinants of FDI inflows into each province.

The FDI literature suggests the general hypothesis that, facing the same set of sources of FDI in the world, provincial differences in FDI inflows are caused by differences in location factors. In this study, we examine five groups of location factors that affect FDI inflows into each of China's host provinces.

\section{Economic factors}

Economic factors include market size, level of economic development, growth rate of the economy, labour cost and productivity, openness of economy to the outside world, and past performance in attracting FDI inflows.

Market size of host province. We may hypothesise that FDI inflows will be greater where the market of the host province is larger. Numerous studies of FDI location determinants suggest that larger economies attract more FDI because of their greater potential market demand. However, this use of provincial market size as a location factor in the provincial distribution of FDI inflows within China needs to be qualified in that provincial market size can be seen to be important for both export-oriented FDI and FDI aimed at serving the whole national market. This is because larger economies can provide more opportunities for industries and enterprises to benefit from external economies of scale and spill-over effects. In these circumstances, the influence of provincial market size will still be positive on the inward FDI to host provinces. In addition, because of the increasing importance of FDI in service sectors, local market size is also a very important location determinant. The measure of market size used in this study is the gross domestic product (GDP) of the host province.

Level of economic development of host province. A province's economic development level is a comprehensive indicator of its economic and social conditions. A higher economic development level not only indicates good overall economic performance and higher purchasing power but also implies higher productivity associated with good labour quality and advanced technology, better local 
infrastructure, and an overall better investment environment. Because the economic development levels of China's provinces vary greatly, we expect that a higher provincial economic development level will have a positive impact on FDI inflows into a province. In this study, per capita GDP, denoted as PGDP, is used as a proxy for the provincial economic development level.

Economic growth rate of host province. A high rate of economic growth is an indicator of development potential. Clearly, markets that are expected to grow faster will tend to attract higher levels of inward FDI. Therefore, we hypothesise that there is a positive relationship between inward FDI and economic growth in the host province. In this study, the real growth rate, denoted by GR, is used as the measure of economic growth in the host province.

Labour costs and productivity in host province. In the FDI literature, the most important factor cost in the determination of FDI flows is the wage rate, especially when $\mathrm{FDl}$ is export-oriented. Therefore, we take the relevant factor cost in the decision to locate FDI in the host province as that of labour costs. In particular, we expect lower labour costs to imply higher levels of FDI inflows, especially for export-oriented FDI. However, a lower wage rate may also be accompanied by lower productivity, meaning the efficiency wage may not be low. The best measure of labour costs would therefore be the 'efficiency wage' rather than the absolute wage rate. In this study, we use the efficiency wage as a measure of labour costs in each host province. The efficiency wage as a measure of labour costs has the advantage of being unit free. It is expected to be negatively related to the level of FDI inflows.

The efficiency wage is measured as

$$
E W_{j}=\frac{W_{j}}{\Pi_{j}}
$$

where $E W_{j}$ is the average efficiency wage in host province $j, W_{j}$ is the average wage rate of all employees in host province $j$, and $\Pi_{j}$ is the overall labour productivity in host province $j$. The provincial overall labour productivity is measured as total valueadded (approximated by GDP) over total employees in each province.

Openness of provinces to the outside world. The level of openness of an economy indicates the intensity of economic interactions between it and the rest of the world. A higher level of openness represents a higher level of international exposure of an economy. Through trade, international business generally lays the ground for inward FDI and the international production that serves to substitute for or complement trade (UNCTAD 2002). In this study, we use two indicators for the openness of an 
economy - the trade to GDP ratio (TGDP) and the export to GDP ratio (EGDP). We expect the level of provincial openness have a positive impact on FDI inflows.

The level of accumulated FDI. Previous studies have found the level of accumulated FDI stock to be an important factor explanator of current FDI inflows (Chen Chunlai, 1997a, 1997b; Petri 1995; Dobson 1993; Mody and Shrinivasan 1991). On the basis of these previous studies, we argue that the level of accumulated FDI stock may have certain demonstration effects on the investment location decision of foreign investors. Consequently, our hypothesis is that a higher level of accumulated FDI stock indicates an overall better investment environment, which may generate demonstration effects and induce higher levels of FDI inflows. Thus, we expect the level of accumulated FDI stock to have a positive effect on attracting new FDI inflows. A province's accumulated FDI, denoted as FDIS, is its FDI inflows accumulated since 1983 at 1995 US dollar prices.

\section{Infrastructure and energy supply}

Intensity of transport infrastructure in host province. The level of transport infrastructure in each host province might be another important consideration for foreign investors. We expect relative length of highways, more railways and interior transport waterways to be positively related to FDI inflows. The proxy for the intensity of transport infrastructure used in this study is the ratio of the sum of the length of highways, railways and interior transport waterways divided by the size of the corresponding host province, denoted as TI. The unit of the intensity of transport infrastructure is kilometres per 100 square kilometres of the host province's land area.

Level of telecommunications of host province. Another important infrastructure variable might be level of telecommunications. Higher levels of telecommunications save time and reduce the costs of communication and information gathering, thus facilitating business activities. Therefore, we expect a province's level of telecommunications to be positively related to its FDI inflows. The level of telecommunications, denoted as TELCOM, is measured by the number of telephone sets per 100 persons in each province.

Energy supply of host province. Energy supply is an important input in many production activities. Therefore, it is expected that energy supply will be positively related to FDI inflows, particularly for manufacturing and efficiency-seeking FDI. In this study, we use electricity production, denoted as EL, as a proxy for energy supply. It is measured by $\mathrm{kWh}$ per capita. 


\section{Human resource endowment and labour quality}

Labour quality in host province. Since labour quality is directly related to labour productivity, it may be another important labour market variable affecting foreign investors' location decisions. In this study we use two measures for labour quality. One is the percentage of the population 15 years or older who are illiterate and semi-literate; the other is the percentage of the total population who are enrolled as university students. We expect the illiterate and semi-literate rate, denoted as NOREAD, to be negatively related to FDI inflows, and the university students enrolment rate, denoted as UNI, to be positively related to FDI inflows.

\section{Geographical location}

China is a large country with a very wide geographical distribution of provinces. Therefore, geographical location might also be an important factor affecting FDI inflows. As mentioned above, based on geographical location, China's 31 mainland provinces can be grouped into East (coastal), Central and West regions. The East coastal provinces are closest to the economic centres of the outside world. Therefore, we use a dummy variable, denoted as COAST, to test the impact of geographical location on FDI inflows. We give a value of one for the 12 provinces along the coastal line and a value of zero for the other provinces. ${ }^{4}$ We expect this dummy variable to have a positive impact on FDI inflows.

\section{Policy factors}

Since China adopted the open door policy more than two decades ago, increasing numbers of cities and areas have gradually opened up to attract FDI and an evolving series of policies towards FDI has been implemented. Have these policies had any significant impact on provincial distribution of FDI inflow? In this study we do not intend to test all policies implemented during the study period. The FDI policies we do test are the Special Economic Zone (SEZ) policies, the uneven regional open policies, and the nationwide FDI promotion policies implemented since the 1990 s.

The uneven regional open policies for FDI were implemented from the establishment of the four SEZs in 1979, to the opening up the 14 coastal cities in 1984, and the expansion of open policies to the eleven coastal provinces in 1988. Not until the early 1990 s did the Chinese government gradually move towards a more even national implementation of open policies for FDI. The policy change in the early 1990 s removed the unfair competition for FDI between the coastal and inland regions, but also 
offered more preferential treatment to foreign investors generally. Preferential policies gradually shifted from favouring some locations to accommodating national and local industrial development policies. Now, any FDI project, as long as it is in line with state or local industrial policy and involves high or new technology, is entitled to preferential treatment, regardless of its location. Second, 52 cities, including all the inland provincial capitals (except Lhasa in Tibet and Urumqi in Xinjiang) and the areas along the Yangzi River,were granted the same preferential policies given to the 14 coastal cities. Third, more than 15 border cities and counties in the southwest, northwest, north and northeast of China were declared open border cities. Fourth, FDI was allowed in certain service industries, such as aviation, telecommunication, banking, insurance and retail trade. Fifth, in order to further develop foreign trade and processing industries in the coastal areas, more duty free bonded zones were planned. Sixth, the government allowed foreign business people, both those intending to set up FDI firms at a later stage and land developers, to buy land use rights for building infrastructure, including residential, commercial, industrial and recreational real estate (Liu Xiangdong et al. 1993; United Nations 1994; Wei Jia 1994).

Since 1997, to reduce the negative impact of the East Asian financial crisis, the Chinese government introduced a series of FDI promotion policies, including the extension of import duty-free treatment of imported equipment for foreign investors, more preferential taxation and other financial policies to encourage foreign investors to invest in targeted industries and the West region further loosened restrictions on FDI in service sectors. The aim was not only to attract more FDI inflows into China but also to encourage foreign investors to invest in certain industries and regions in accordance with China's national economic development strategy (MOFTEC 1997, 1999).

China has made substantial commitments in trade and investment liberalisation with its accession to the WTO, which will have a positive impact on FDI inflows into China's economy.

Three dummy variables, denoted as SEZ, ROP and P, for the Special Economic Zone policy, the regional open policy and FDI promotion policies implemented since the 1990s, are tested for their impact on the inflow of FDI. For the dummy variable SEZ, we give a value of one for Guangdong, Fujian, Hainan and Shanghai, and a value of zero for other provinces. For the dummy variable ROP, we give a value of one for the 12 eastern provinces from 1986 to 2002, and values of zero from 1986 to 1991 and one from 1992 to 2002 for other provinces. For the dummy variable $P$, 
we give a value of zero for the years from 1986 to 1991 and a value of one for the years from 1992 to 2002 for all provinces.

\section{LOCATION DETERMINANTS OF FDI DISTRIBUTION WITHIN CHINA-AN EMPIRICAL ANALYSIS}

\section{Variable specification and the model}

The relationship between inflows of $\mathrm{FDI}$ and location variables in China's provinces is investigated over time and across provinces. The Kmenta Model, an approach (Pool) designed especially for pooled time-series and cross-section data in the SHAZAM econometrics computer program is used. As this method applies the Generalised Least Square (GLS) technique to pooled data, taking time-wise autocorrelation and cross-sectional heteroskedasticity into account, it will produce a more efficient regression estimation than other methods. Furthermore, with the pooled data, the observations are much larger than would be the case if just timeseries or cross-sectional data were employed. Consequently, the reliability of the estimates of the regression parameters can be greatly increased.

Data on 29 provinces for the period 1986-2002 are included. ${ }^{5}$ In this study, the dependent variable, denoted as $\mathrm{FDI}_{\mathrm{r}_{\mathrm{j}, \mathrm{t}}}$, is the aggregate inflow of actual FDI from all source countries and economies into China's host province j in year t. The value of FDI is at constant 1995 US dollar prices. There are 16 independent variables, as summarised in Table 12.4.

We establish the following equation to test the location determinants of the provincial distribution of FDI inflows into China.

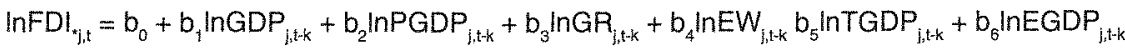

$$
\begin{aligned}
& +b_{7} \operatorname{InFDIS} S_{j, k-k}+\left.b_{8} \operatorname{lnT}\right|_{j,-k}+\left.b_{9} \operatorname{InTELCOM}\right|_{j, t-k}+b_{10} \ln E L_{j, k-k}+b_{11} \ln U N_{j, t, k} \\
& +b_{12} \operatorname{InNOREAD~}_{j, t-k}+b_{13} \text { COAST }_{j}+b_{14} S_{14} Z_{j}+b_{15} R^{2} P_{j, t}+b_{16} P_{t}+e_{j, t}
\end{aligned}
$$

where $e_{j, t}$ is stochastic disturbance, the $b s$ are the regression parameters to be estimated, and the variables are as defined above. The estimated coefficients of all variables except the dummy variables will be elasticities.

The independent variables, except for the dummy variables, are lagged $k$ years. This model assumes that the effect of the independent variables at time $t-k$ appears only within period $t$ and is fully completed within that period. The relationship shown in the above equation will be examined for $k=1$, the most likely appropriate lag. 
Table 12.4 List of variables of provincial FDI inflow equation

\begin{tabular}{|c|c|c|}
\hline Variable name & Specification of variables & $\begin{array}{l}\text { Expected impact } \\
\text { on } \mathrm{FDl} \text { inflow }\end{array}$ \\
\hline \multicolumn{3}{|c|}{ Dependent variable } \\
\hline $\mathrm{FDI}_{\mathrm{j}, \mathrm{i}}$ & $\begin{array}{l}\text { Aggregate FDI inflows from all source countries } \\
\text { into province j in year t. Million US dollars at } 1995 \\
\text { constant prices. }\end{array}$ & \\
\hline \multicolumn{3}{|c|}{ Independent variables } \\
\hline$G D P_{i, t}$ & $\begin{array}{l}\text { GDP of province } j \text { in year t. Renminbi million yuan } \\
\text { at } 1995 \text { constant prices. }\end{array}$ & Positive \\
\hline $\mathrm{PGDP}_{i, \mathrm{t}}$ & $\begin{array}{l}\text { Per capita GDP of province j in year t. Renminbi } \\
\text { yuan per capita at } 1995 \text { constant prices. }\end{array}$ & Positive \\
\hline $\mathrm{GR}_{i, \mathrm{i}}$ & Real growth rate of GDP of province j in year $t$ & Positive \\
\hline$E W_{i, t}^{n+1}$ & Efficiency wage of province $\mathrm{j}$ in year $\mathrm{t}$. & Negative \\
\hline$T / G D P_{j, t}$ & Total trade to GDP ratio of province $\mathrm{j}$ in year $\mathrm{t}$. & Positive \\
\hline$E / G D P_{j, t}$ & Export to GDP ratio of province $\mathrm{j}$ in year $\mathrm{t}$. & Positive \\
\hline $\mathrm{FDIS}_{\mathrm{j}, \mathrm{t}}$ & $\begin{array}{l}\text { Accumulated FDI stocks of province } j \text { at the end } \\
\text { of year t. Million US dollars at } 1995 \text { constant prices. }\end{array}$ & Positive \\
\hline $\mathrm{TI}_{\mathrm{j}, \mathrm{t}}$ & $\begin{array}{l}\text { Transport intensity index of province j in year t. } \\
\text { Kilometres per } 100 \text { square kilometres. }\end{array}$ & Positive \\
\hline TELCOM $_{\mathrm{j}, \mathrm{i}}$ & $\begin{array}{l}\text { Level of telecommunications of province } \mathrm{j} \text { in year } \mathrm{t} \text {. } \\
\text { Number of telephone sets per } 100 \text { persons. }\end{array}$ & Positive \\
\hline $\mathrm{EL}_{\mathrm{j}, \mathrm{t}}$ & $\begin{array}{l}\text { Level of electricity supply of province j in year t. } \\
\text { kWh per capita. }\end{array}$ & Positive \\
\hline$U N I_{j, t}$ & $\begin{array}{l}\text { University students enrolment rate of province } \\
\mathrm{j} \text { in year t. }\end{array}$ & Positive \\
\hline NOREAD $_{\mathrm{j}, \mathrm{i}}$ & $\begin{array}{l}\text { Illiterate and semi-literate rate of population } 15 \\
\text { years or older of province } j \text { in year } t .\end{array}$ & Negative \\
\hline $\operatorname{COAST}_{j, t}$ & $\begin{array}{l}\text { Geographical location dummy variable. One for } \\
\text { the } 12 \text { provinces located along the coastline, and } \\
\text { zero for other provinces. }\end{array}$ & Positive \\
\hline$S E Z_{j, t}$ & $\begin{array}{l}\text { Special Economic Zone dummy variable. One for } \\
\text { Guangdong, Fujian, Hainan and Shanghai, zero for } \\
\text { other provinces. }\end{array}$ & Positive \\
\hline $\mathrm{ROP}_{\mathrm{j}, \mathrm{i}}$ & $\begin{array}{l}\text { Regional open policy dummy variable. One for the } 12 \\
\text { coastal economically opened provinces. Zero from } \\
1986 \text { to } 1991 \text { and one from } 1992 \text { to } 2002 \text { for other } \\
\text { provinces. }\end{array}$ & Positive \\
\hline $\mathrm{P}_{\mathrm{t}}$ & $\begin{array}{l}\text { Policy dummy variable. Zero for the years } 1986 \text { to } \\
1991 \text {, one for the years } 1992 \text { to } 2002 \text {. }\end{array}$ & Positive \\
\hline
\end{tabular}

Note: All the variables are calculated from the State Statistical Bureau, 1986-2002. Zhongguo TongjiNianjian, [China Statistical Yearbook]. 


\section{Regression results and explanations}

Table 12.5 shows the regression results of the provincial aggregate FDI inflow equation with the explanatory variables, except for the dummy variables, lagged 1 year $(k=1)$ for 29 provinces for the period 1986-2002.

Since there are 16 independent variables, before running the regression, we conducted a correlation test for the independent variables. We found the correlation coefficients between some of the independent variables to be very high. The high correlation between these independent variables may incur high multicolinearity problems if we enter all the independent variables into the same regression equation. Therefore, we split the original equation into two independent models. The result is shown in Table 12.5 (model 1 and model 2). By using the Chow test, the F-statistic is equal to 1.390 , which is less than the critical value (5.89 at 5 per cent level). Thus, we accept the $\mathrm{H}_{0}$ : the decomposition of the equation is reasonable. Furthermore, we split the original model into five independent models. By using a similar method, the F-statistic to be equal to 1.936 , which is less than the critical value (18.5 at 5 per cent level). Thus, we accept the $\mathrm{H}_{0}$ : the decomposition of the equation is valid. ${ }^{6}$

Therefore, we ran seven separate regressions each with a different set of explanatory variables. The seven models performed well. All regressions have relatively high explanatory power and all the independent variables have the expected signs and are statistically significant.

The regression results show that provincial differences in FDI inflows can be explained by differences in provincial location factors. The provincial market size (GDP), the level of economic development (PGDP), the growth rate of provincial economy (GR), the trade and export to GDP ratios (TGDP and EGDP), the level of accumulated FDI stock (FDIS), the intensity of transport infrastructure (TI), the level of telecommunications (TELCOM), the level of energy supply (EL) and the university student enrolment rate (UNI) are positive and statistically significant location determinants of the provincial distribution of FDI. Meanwhile, the provincial efficiency wage $(E W)$, the proxy for labour costs adjusted for productivity, and the provincial illiterate and semi-literate rates are negative and statistically significant location determinants affecting FDI inflows. The geographical location (COAST), the Special Economic Zone policies (SEZ), and the regional differentiation in the timing of implementing the open policies (ROP) for FDI have had a strong impact on the provincial distribution of FDI inflows into China. This indicates that, apart from economic factors, FDI inflows into the East region were enhanced by the geographical 
location advantage, the special policies to the SEZs, and the implementation of the uneven regional open policies for FDI during the 1980s. The gradual but obvious diffusion of FDI inflows into the inland provinces after 1992 is also partly due to the nationwide implementation of open policies for FDI since the early 1990 s. Finally, the series of FDI promotion policies ( $P$ ) implemented in the early 1990 s had strong positive effects on inflows of FDI into China across all provinces. Therefore, the sharp increase in the inflows of FDI into China since 1992 can be explained partly by the major favourable policy towards FDI made in the early 1990s and the trade and investment liberalisation that continued throughout the 1990s.

\section{INWARD FDI ATTRACTIVENESS INDEX OF CHINA'S PROVINCES}

With the empirical test results, we can construct the inward FDI attractiveness index for China's provinces using the provincial location factors affecting FDI inflows. We adopt the same method used by UNCTAD (2002). ${ }^{7}$ The provincial inward FDI attractiveness index is the average of the scores on fifteen variables (including three dummy variables) for each province. The scores for each variable, except the dummy variables are derived from using the following formula

$$
\text { Score }=\left(V_{1}-V_{\min }\right) /\left(V_{\max }-V_{\text {min }}\right)
$$

where $V_{i}=$ the value of a variable for the province $i$

$V_{\text {min }}=$ the lowest value of the variable among the provinces

$V_{\max }=$ the highest value of the variable among the provinces.

According to the above formula, for each variable the province with the lowest value is given a score of zero and the province with the highest value is given a score of one. For dummy variables, the province with the value of zero is given a score of zero and the province with the value of one is given a score of one.

The variables used in the calculation of the provincial inward FDI attractiveness index include provincial GDP, per capita GDP, real economic growth rate, cost adjusted productivity (the inverse of the efficiency wage), trade to GDP ratio, export to GDP ratio, accumulated FDI stock, level of transportation infrastructure, level of telecommunications, electricity supply, university student enrolment rate, literacy rate (the opposite of the illiteracy rate), and three dummy variables, that is, the location dummy variable of COAST, the special economic zone policy dummy variable of SEZ and the dummy variable of $P$ representing the trade and FDI liberalisation policies implemented since 1992. 


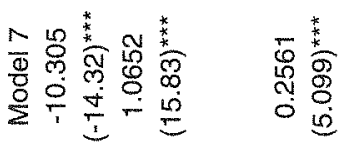

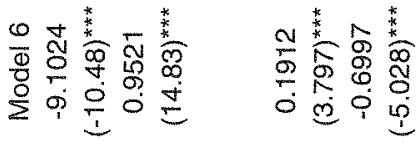

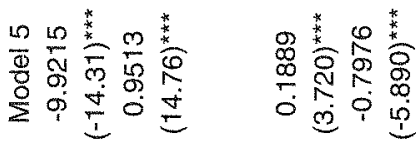

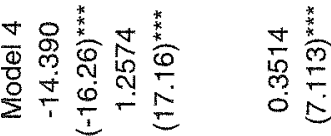

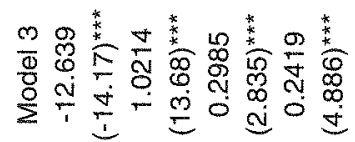

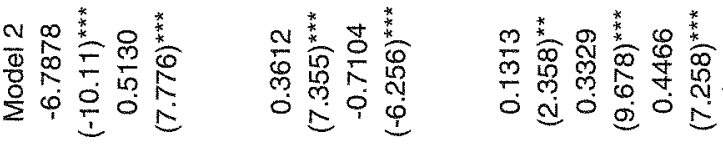

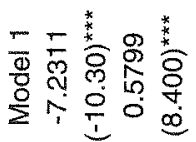

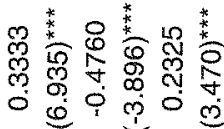

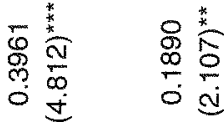

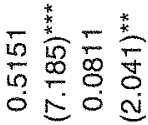

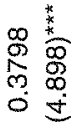

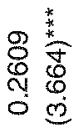

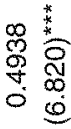

导 


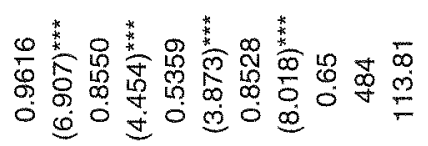

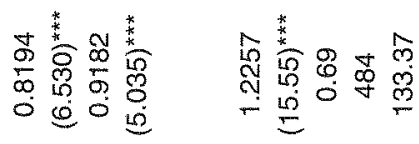

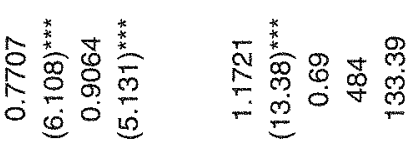

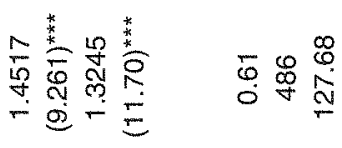

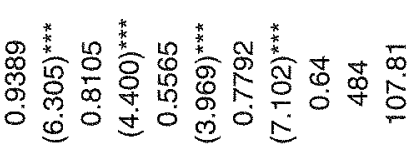

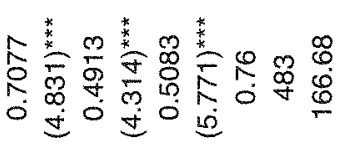

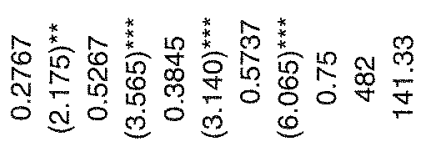

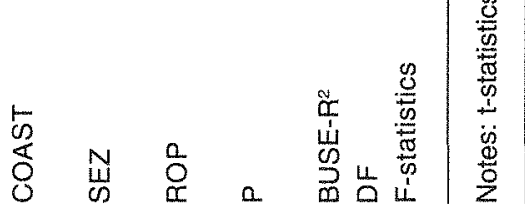


The provincial inward FDI attractiveness index is calculated for the four periods, 1985-89, 1990-94, 1995-99 and 2000-02 (Table 12.6). The interesting results of the calculation can be summarised as follows. First, index values among China's 31 mainland provinces differ greatly and are consistent with the provincial distribution of FDI inflows into China.

Second, for all four periods, Shanghai, Guangdong, Beijing and Tianjin have remained the top four provinces with the highest index values, while Tibet, Guizhou, Gansu, Yunnan and Qinghai have remained the bottom five provinces with the lowest index values.

Third, in terms of the inward FDI attractiveness index values, for all four periods, the top ten provinces are all located in the East region, while of the bottom ten provinces two are located in the Central region and eight in the West region. As a result, the East region has the highest index values, around two and two and a half times higher respectively than those in the Central and West regions.

Fourth, over time, the index values for all three regions and provinces have increased, indicating that for the last two decades or so, the investment environment for FDI has steadily improved across China. Among the provinces, the largest lifts in the ranks of the inward FDI attractiveness index are by Jiangsu and Zhejiang in the East region and Hubei in the Central region.

Finally, compared with the East region, although there has been some improvement in the investment environment for FDI, the Central and particularly the West regions still have very low FDI attractiveness in terms of location factors. On a comparable basis, the attractiveness to FDI of the Central and West regions lag 10-15 years behind that of the East region. Because the inward FDI attractiveness index values are largely based on structural economic factors that tend to change slowly over time, it is unrealistic to expect that the Central region and particularly the West region will attract large FDI inflows in the near future.

\section{CONCLUSION}

This paper has investigated empirically the provincial distribution of FDI inflows into China during the reform period, particularly since the late 1980s. The provincial distribution has been very uneven. The East region provinces received the overwhelming share, while the Central and West regions received only around 10 per cent of total FDI inflows into China during the period 1983-2002. The causes of 
Table 12.6 Provincial FDI attractiveness index $($ minimum $=0$, maximum $=1)$

\begin{tabular}{|c|c|c|c|c|c|c|c|c|}
\hline \multirow[t]{2}{*}{ Province } & \multicolumn{2}{|c|}{$1985-89$} & \multicolumn{2}{|c|}{$1990-94$} & \multicolumn{2}{|c|}{$1995-99$} & \multicolumn{2}{|c|}{$2000-02$} \\
\hline & Value & Rank & Value & Value & Rank & Rank & Value & Rank \\
\hline East region & 0.40 & 1 & 0.48 & 1 & 0.51 & 1 & 0.52 & 1 \\
\hline Beijing & 0.53 & 3 & 0.58 & 3 & 0.60 & 3 & 0.62 & 3 \\
\hline Tianjin & 0.45 & 4 & 0.49 & 4 & 0.57 & 4 & 0.61 & 4 \\
\hline Hebel & 0.28 & 10 & 0.33 & 11 & 0.38 & 10 & 0.37 & 11 \\
\hline Liaoning & 0.42 & 5 & 0.43 & 8 & 0.44 & 8 & 0.45 & 8 \\
\hline Shanghai & 0.65 & 1 & 0.76 & 1 & 0.81 & 1 & 0.83 & 1 \\
\hline Jiangsu & 0.37 & 7 & 0.43 & 7 & 0.50 & 6 & 0.53 & 5 \\
\hline Zhejiang & 0.32 & 9 & 0.41 & 9 & 0.45 & 7 & 0.48 & 7 \\
\hline Fujian & 0.38 & 6 & 0.49 & 5 & 0.54 & 5 & 0.51 & 6 \\
\hline Shandong & 0.32 & 8 & 0.40 & 10 & 0.43 & 9 & 0.45 & 9 \\
\hline Guangdong & 0.61 & 2 & 0.71 & 2 & 0.72 & 2 & 0.73 & 2 \\
\hline Guangxi & 0.21 & 15 & 0.29 & 12 & 0.29 & 14 & 0.27 & 16 \\
\hline Hainan & 0.25 & 11 & 0.45 & 6 & 0.38 & 11 & 0.40 & 10 \\
\hline Central region & 0.18 & 2 & 0.24 & 2 & 0.27 & 2 & 0.27 & 2 \\
\hline Shanxi & 0.17 & 19 & 0.24 & 17 & 0.27 & 16 & 0.27 & 15 \\
\hline Inner Mongolia & 0.17 & 21 & 0.22 & 20 & 0.24 & 20 & 0.27 & 17 \\
\hline Jilin & 0.22 & 12 & 0.27 & 14 & 0.28 & 15 & 0.30 & 14 \\
\hline Heilongjiang & 0.22 & 13 & 0.28 & 13 & 0.31 & 13 & 0.30 & 13 \\
\hline Anhui & 0.15 & 25 & 0.21 & 23 & 0.25 & 19 & 0.23 & 24 \\
\hline Jiangxi & 0.16 & 24 & 0.21 & 22 & 0.24 & 21 & 0.23 & 26 \\
\hline Henan & 0.18 & 17 & 0.23 & 18 & 0.27 & 17 & 0.27 & 18 \\
\hline Hubei & 0.21 & 14 & 0.27 & 15 & 0.31 & 12 & 0.30 & 12 \\
\hline Hunan & 0.18 & 18 & 0.22 & 19 & 0.26 & 18 & 0.25 & 20 \\
\hline West region & 0.13 & 3 & 0.18 & 3 & 0.20 & 3 & 0.21 & 3 \\
\hline Chongqing &.. & & $\ldots$ & & .. & & 0.23 & 25 \\
\hline Sichuan & 0.16 & 23 & 0.21 & 21 & 0.23 & 25 & 0.23 & 27 \\
\hline Guizhou & 0.09 & 29 & 0.14 & 29 & 0.17 & 29 & 0.18 & 29 \\
\hline Yunnan & 0.13 & 27 & 0.17 & 26 & 0.20 & 26 & 0.18 & 30 \\
\hline Tibet & 0.01 & 30 & 0.09 & 30 & 0.14 & 30 & 0.14 & 31 \\
\hline Shaanxi & 0.18 & 16 & 0.20 & 24 & 0.23 & 24 & 0.24 & 22 \\
\hline Gansu & 0.13 & 26 & 0.15 & 28 & 0.18 & 27 & 0.19 & 28 \\
\hline Qinghai & 0.11 & 28 & 0.16 & 27 & 0.18 & 28 & 0.23 & 23 \\
\hline Ningxia & 0.16 & 22 & 0.20 & 25 & 0.23 & 23 & 0.26 & 19 \\
\hline Xinjiang & 0.17 & 20 & 0.24 & 16 & 0.24 & 22 & 0.25 & 21 \\
\hline
\end{tabular}

Source: Author's calculation. 
this uneven provincial distribution were made the subject of theoretical explanation and empirical investigation.

Using Dunning's 'OLI' explanation of the causes of FDI with a focus on location advantages, our empirical analysis has shown that given the ownership advantages of source countries and the incentives for their multinational enterprises (MNEs) to internalise their ownership advantages in order to reduce transaction costs, the location advantages or determinants of host provinces are crucial in attracting FDI inflows. In other words, given the same set of source countries, provincial differences in FDI inflows are determined by differences in the location advantages of host provinces. Therefore, the uneven provincial distribution of FDI inflows into China is caused by the differences in provincial location factors.

Strong support for the hypotheses set out in the fourth section of this chapter was provided by the empirical regression analysis. To summarise, the provinces with larger GDP, higher per capita income, higher rate of economic growth, higher level of openness represented by trade and export to GDP ratios, higher level of accumulated FDI stock, more intensive transport infrastructure, higher level of telecommunications, higher level of electricity supply, higher level of labour quality and R\&D potential represented by higher ratio of university student enrolment, and coastal location attracted greater FDI inflows. Meanwhile, higher labour costs approximated by efficiency wages and lower labour quality approximated by illiterate and semi-literate ratios deterred FDI inflows. In addition, the SEZ policies and regional differentiation in the timing of implementation of the open policies for FDI had a strong impact on the provincial distribution of FDI inflows. Finally, the implementation of a series of trade and FDI liberalisation policies in the 1990s had a very strong positive effect on FDI inflows into China across all provinces.

Based on the empirical analysis, we constructed the provincial inward FDI attractiveness index for mainland China's 31 provinces. There are large differences among China's 31 mainland provinces in the attractiveness to FDI inflows. The most attractive provinces are the East region provinces, particularly Shanghai, Guangdong, Beijing, Tianjin, Jiangsu, Fujian, Zhejiang and Shandong. Although there have been some improvements in their investment environments, the Central region provinces, and particularly the West region provinces, remain less attractive to FDI than the East. The East region will continue to attract most of the FDI inflows into China, and uneven regional distribution of FDI inflows into China will persist. 
Two important implications for the provincial distribution of FDI in China can be drawn from this study. First, it is essential for each of the provinces to boost economic growth, to increase per capita income, to increase interaction with the world economy, to enhance education and labour training, to raise labour productivity, and to improve basic infrastructure in order to attract more FDI inflows. Though this will not be easy for all of the provinces, especially not for economically backward provinces in the West region, it is crucial if they are to attract more FDI to accelerate economic development. Second, since China launched the overall economic reform in the late 1979, the economic growth rates of the East region provinces, which benefited from regionally biased special policies, have been much faster than those of the less developed inland and West region provinces. This unbalanced economic growth between the coastal and the inland and western provinces has led to uneven economic development and the widening of the income gap between them. Though policies open to FDI have been followed throughout China since 1992, differences between the East region provinces and the Central and West region provinces resulting from time lag of policy implementation will not be eliminated in the near future. To hasten the economic development of inland provinces, particularly the less developed western areas, China should

- shift the preferential policies for FDI from regional priority to industrial priority, in order to support those FDI projects engaged in export-oriented, technologically advanced, transportation, communication, energy and raw materials industries

- adjust its regional development strategy by offering special economic and industrial development policies to the Central and West regions (the launch of the 'West Region Development Strategy' in 1998 was an important step in the right direction)

- encourage coastal areas to transfer managerial skills and technology accumulated and obtained from attracting and utilising FDI to the inland regions in order to benefit fully from FDI nationwide.

\section{NOTES}

1 Shenzhen, Zhuhai, and Shantou in Guangdong Province, and Xiamen in Fujian Province.

2 Liaoning, Tianjin, Hebei, Shandong, Shanghai, Jiangsu, Zhejiang, Fujian, Guangdong and Guangxi.

${ }^{3}$ The East region includes Beijing, Tianjin, Hebei, Liaoning, Shanghai, Jiangsu, Zhejiang, Fujian, Shandong, Guangdong, Guangxi, and Hainan. The Central region includes Shanxi, Inner Mongolia, 
Jilin, Heilongjiang, Anhui, Jiangxi, Henan, Hubei, and Hunan. The West region includes Chongqing, Sichuan, Guizhou, Yunnan, Tibet, Shaanxi, Gansu, Qinghai, Ningxia, and Xinjiang.

4 The twelve coastal provinces are Beijing, Tianjin, Hebei, Liaoning, Shanghai, Jiangsu, Zhejiang, Fujian, Shandong, Guangdong, Guangxi, and Hainan.

5 Tibet and Chongqing are excluded from the test because of insufficient data. Tibet attracted only US\$20,000 FDI inflow in 1988 and Chongqing was separated from Sichuan in 1997.

6 I would like to thank Mr Sheng Yu for his help in conducting the tests.

7 Though UNCTAD names it the 'inward FDI potential index', I prefer to call it the 'inward FDI attractiveness index'.

\section{REFERENCES}

Balasubramanyam, V. and Greenaway, D., 1994. 'East Asian foreign direct investment in the EC', in V. Balasubramanyam and D. Sapsford (eds), The Economics of International Investment, Edward Elgar, Brookfield, Vermont:103-28.

Broadman, G. and Sun Xiaolun, 1997. 'The distribution of foreign direct investment in China', The World Economy, 20(3):339-61.

Chen Chien-Hsun, 1996. 'Regional determinants of foreign direct investment in mainland China', Journal of Economic Studies, 23(2):18-30.

Chen Chunlai, 1997a. The Location Determinants of Foreign Direct Investment in Developing Countries, Working Paper, 12, Chinese Economies Research Centre, University of Adelaide, Adelaide.

$\longrightarrow$ - 1997b. Provincial Characteristics and Foreign Direct Investment Location Decision within China, Working Paper 16, Chinese Economies Research Centre, University of Adelaide, Adelaide.

Coughlin, C., Terza, J. and Arromdee, V., 1991. 'State characteristics and the location of foreign direct investment within the United States', Review of Economics and Statistics, 73(4):675-83.

Dobson, W., 1993. Japan in East Asia: trading and investment strategies, Institute of Southeast Asian Studies, Singapore.

Dunning, J., 1993. Multinational Enterprises and the Global Economy, AddisonWesley, Wokingham, England.

MOFTEC, 1997. Tax Exemption Policies on Importation of Equipment by MOFTEC Enterprises with Foreign Investment, Foreign Investment Administration, Ministry of Foreign Trade and Economic Cooperation, Beijing. 
MOFTEC, 1999. Measures for Further Encouraging Foreign Direct Investment, Foreign Investment Administration, Ministry of Foreign Trade and Economic Cooperation, Beijing.

Hultman, C. and McGee, L., 1988. 'Factors influencing foreign investment in the US, 1970-1986', Rivista Internazionale di Scienze Economiche e Commerciali, 35(1011):1061-6.

Lim, D., 1983. 'Fiscal incentives and direct foreign investment in less developed countries', The Journal of Development Studies, 19(2):207-12.

Liu Xiangdong, He Cun, Lu Zheng, Fan Baoqing and Zhou Jie (eds), 1993. Zhongguo Duiwai Jingji Maoyi Zhengce Zhinan [Guide to China's Foreign Economic and Trade Policies], Jingji Guanli Chubanshe, Beijing.

Milner, C. and Pentecost, E., 1994. 'The determinants of the composition of US foreign direct investment in UK manufacturing', in V. Balasubramanyam and D. Sapsford (eds), The Economics of International Investment, Edward Elgar, Brookfield, Vermont:85-102.

Mody, A. and Shrinivasan, K., 1991. Trends and Determinants of Foreign Direct linvestment: an empirical analysis of US investment abroad, World Bank, Washington, DC (unpublished).

Nigh, D., 1985. 'The effect of political events on United States direct foreign investment: a pooled time-series cross-sectional analysis', Journal of International Business Studies, 16(1): 1-17.

Petri, P., 1995. 'The interdependence of trade and investment in the Pacific', in E. Chen and P. Drysdale (eds), Corporate Links and Foreign Direct Investment in Asia and the Pacific, Harper Educational Publishers, Pymble:29-55.

Riedel, J., 1975. 'The nature and determinants of export-oriented direct foreign investment in a developing country: a case study of Taiwan', Weltwirtschaftliches Archiv, 111(3):505-28.

Scaperlanda, A. and Mauer, L.,1969. 'The determinants of US direct investment in the EEC', American Economic Review, 59(4):558-68.

State Statistical Bureau, various years. Zhongguo Tongji Nianjian 1986-2002 [China Statistical Yearbook], Zhongguo Tongji Chubanshe, Beijing.

State Statistical Bureau, 1992. Zhongguo Duiwai Jingji Tongji Daquan 1979-1991 [China Foreign Economic Statistics 1979-91], China Statistical Information \& Consultancy Service Centre, Beijing. 
Torrisi, C., 1985. 'The determinants of direct foreign investment in a small LDC', Journal of Economic Development, 10(1):29-45.

United Nations, 1994. World Investment Report 1994: transnational corporations, employment and the workplace, United Nations Publications, New York and Geneva.

United Nations, 1995. World Investment Report 1995: transnational corporations and competitiveness, United Nations Publications, New York and Geneva.

United Nations, 2002. World Investment Report 2002: transnational corporations and export competitiveness, United Nations Publication, New York and Geneva.

Wei Jia, 1994. Chinese Foreign Investment Laws and Policies: evolution and transformation, Quorum Books, Westport, Connecticut.

Wei Shangjin, 1995. 'Attracting foreign direct investment: has China reached its potential?', China Economic Review, 6(2):187-99.

Wheeler, D. and Mody, A.,1992. 'International investment location decisions: the case of US firms', Journal of International Economics, 33(1-2):57-76.

Zhang Leyin, 1994. 'Location-specific advantages and manufacturing direct foreign investment in south China', World Development, 22(1):45-53. 